\title{
Adiponectin induces insulin secretion in vitro and in vivo at a low glucose concentration
}

\author{
M. Okamoto $\cdot$ M. Ohara-Imaizumi • N. Kubota • \\ S. Hashimoto $\cdot$ K. Eto $\cdot$ T. Kanno $\cdot$ T. Kubota $\cdot$ \\ M. Wakui $\cdot$ R. Nagai $\cdot$ M. Noda $\cdot$ S. Nagamatsu $\cdot$ \\ T. Kadowaki
}

Received: 17 October 2007 / Accepted: 20 December 2007 / Published online: 28 March 2008

(C) Springer-Verlag 2008

\begin{abstract}
Aims/hypothesis A decrease in plasma adiponectin levels has been shown to contribute to the development of diabetes. However, it remains uncertain whether adiponectin plays a role in the regulation of insulin secretion. In this study, we investigated whether adiponectin may be involved in the regulation of insulin secretion in vivo and in vitro.

Methods The effect of adiponectin on insulin secretion was measured in vitro and in vivo, along with the effects of adiponectin on ATP generation, membrane potentials, $\mathrm{Ca}^{2+}$ currents, cytosolic calcium concentration and state of 5'-AMP-activated protein kinase (AMPK). In addition, insulin granule transport was measured by membrane capacitance and total internal reflection fluorescence (TIRF) analysis.
\end{abstract}

M. Okamoto and M. Ohara-Imaizumi contributed equally to this study.

Electronic supplementary material The online version of this article (doi:10.1007/s00125-008-0944-9) contains supplementary material, which is available to authorised users.

M. Okamoto $\cdot$ N. Kubota $\cdot$ S. Hashimoto $\cdot$ K. Eto $\cdot$ T. Kubota $\cdot$

T. Kadowaki $(\bowtie)$

Department of Metabolic Diseases, Graduate School of Medicine,

University of Tokyo,

Hongo 7-3-1, Bunkyo-ku,

Tokyo 113-8655, Japan

e-mail: kadowaki-3im@h.u-tokyo.ac.jp

M. Ohara-Imaizumi $\cdot$ S. Nagamatsu

Department of Biochemistry,

Kyorin University School of Medicine,

Tokyo, Japan

N. Kubota $\cdot$ T. Kubota $\cdot$ T. Kadowaki

Division of Applied Nutrition,

National Institute of Health and Nutrition,

Tokyo, Japan
Results Adiponectin significantly stimulated insulin secretion from pancreatic islets to approximately 2.3 -fold the baseline value in the presence of a glucose concentration of $5.6 \mathrm{mmol} / \mathrm{l}$. Although adiponectin had no effect on ATP generation, membrane potentials, $\mathrm{Ca}^{2+}$ currents, cytosolic calcium concentrations or activation status of AMPK, it caused a significant increase of membrane capacitance to approximately 2.3 -fold the baseline value. TIRF analysis revealed that adiponectin induced a significant increase in the number of fusion events in mouse pancreatic beta cells under $5.6 \mathrm{mmol} / \mathrm{l}$ glucose loading, without affecting the status of previously docked granules. Moreover, intravenous injection of adiponectin significantly increased insulin secretion to approximately 1.6-fold of baseline in C57BL/6 mice.

T. Kanno $\cdot$ M. Wakui

Department of Physiology,

Hirosaki University School of Medicine,

Hirosaki, Japan

R. Nagai

Department of Cardiovascular Medicine,

Graduate School of Medicine, University of Tokyo,

Tokyo, Japan

M. Noda

Department of Diabetes and Metabolic Medicine,

International Medical Center of Japan,

Tokyo, Japan 
Conclusions/interpretation The above results indicate that adiponectin induces insulin secretion in vitro and in vivo.

Keywords Adiponectin - Beta cell · Capacitance .

Fusion events · Insulin granules · Insulin secretion · Islet

$\begin{array}{ll}\text { Abbreviations } \\ \text { AICAR } & \text { 5-amino-imidazole-4-carboxamide riboside } \\ \text { AMPK } & \text { 5'-AMP-activated protein kinase } \\ {\left[\mathrm{Ca}^{2+}\right]_{\mathrm{c}}} & \text { cytosolic } \mathrm{Ca}^{2+} \text { concentration } \\ \text { GFP } & \text { green fluorescent protein } \\ \text { LPS } & \text { lipopolysaccharide } \\ \text { TIRF } & \text { total internal reflection fluorescence }\end{array}$

\section{Introduction}

The adipocyte-derived hormone adiponectin (also known as Acrp30, GBP28 or AdipoQ) [1-4] has been shown to play important roles in the regulation of glucose and lipid metabolism. Plasma adiponectin levels are reduced in obese and insulin-resistant humans and in animal models $[2,5,6]$. Adiponectin improves insulin sensitivity in muscle and liver by enhancing fatty acid oxidation via activation of 5'-AMP-activated protein kinase (AMPK) $[7,8]$ and peroxisome proliferator-activated receptor $\alpha[6,9]$.

We previously demonstrated that adiponectin-deficient $\left(\right.$ Adipo $^{-/-}$) mice exhibit insulin resistance [10], but that after glucose loading the plasma insulin levels tended to be lower in Adipo $^{-1-}$ mice than in wild-type mice, suggesting that adiponectin may induce insulin secretion [10]. The adiponectin receptors ADIPOR 1 and ADIPOR2 have recently been cloned [11] and identified in human and rat pancreatic beta cells [12]. Expression of the adiponectin receptors by INS-1 cells (a clonal rat beta cell line) has been found to increase following exposure to oleic acid, an unsaturated NEFA. Moreover, a previous study has suggested that adiponectin also exerts anti-apoptotic actions and that this protective function of adiponectin might serve to counteract autoimmune- and lipotoxicity-induced beta cell destruction [13]. However, it is still uncertain whether adiponectin plays a role in the regulation of insulin secretion. In this study we investigated whether adiponectin might be involved in the regulation of insulin secretion in vitro and in vivo.

\section{Methods}

Animals C57BL/6 mice were obtained from CLEA Japan (Tokyo, Japan). Male C57BL/6 mice (10 to 16 weeks old) were housed under a $12 \mathrm{~h}$ light-dark cycle and given free access to food. The animal care and experimental procedures were approved by the Animal Care Committee of the University of Tokyo.

$R N A$ preparation and real-time quantitative $P C R$ Total RNA was extracted from isolated islets using TRIzol reagent (Invitrogen, Carlsbad, CA, USA) according to the manufacturer's instructions. cDNA synthesis was performed using the SuperScript Preamplification System (Invitrogen), followed by TaqMan quantitative PCR (Applied Biosystems, Foster City, CA, USA; $50^{\circ} \mathrm{C}$ for 2 min and $95^{\circ} \mathrm{C}$ for $10 \mathrm{~min}$, followed by 40 cycles of $95^{\circ} \mathrm{C}$ for $15 \mathrm{~s}$ and $60^{\circ} \mathrm{C}$ for $1 \mathrm{~min}$ ) with an ABI Prism 7000 PCR instrument (Applied Biosystems) to amplify samples of the Adipor1, Adipor 2 and $\beta$-actin genes. The sequences of the primers and probes are described elsewhere [11].

Insulin secretion by islets Islets were isolated from 10- to 16-week-old C57BL/6 mice as described elsewhere [14]. In brief, after clamping the common bile duct at a point close to the duodenal outlet, $2.5 \mathrm{ml} \mathrm{KRB}(129 \mathrm{mmol} / \mathrm{l} \mathrm{NaCl}$, $4.8 \mathrm{mmol} / 1 \mathrm{KCl}, 1.2 \mathrm{mmol} / 1 \mathrm{MgSO}_{4}, 1.2 \mathrm{mmol} / 1 \mathrm{KH}_{2} \mathrm{PO}_{4}$, $2.5 \mathrm{mmol} / 1 \mathrm{CaCl}_{2}, 5 \mathrm{mmol} / 1 \mathrm{NaHCO}_{3}$ and $10 \mathrm{mmol} / \mathrm{l} \mathrm{HEPES}$; $\mathrm{pH}$ 7.4) containing $4 \mathrm{mg} / \mathrm{ml}$ collagenase (Sigma, St Louis, MO, USA) was injected into the duct. Insulin release by the pancreatic islets was measured by static incubation with KRB containing $0.2 \%$ (wt/vol.) bovine serum albumin [15]. In the static incubation, batches of ten freshly isolated islets were preincubated at $37^{\circ} \mathrm{C}$ for $30 \mathrm{~min}$ in $\mathrm{KRB}$ containing $2.8 \mathrm{mmol} / 1$ glucose. The preincubation solutions were replaced with KRB containing test agents and the batches of islets were incubated at $37^{\circ} \mathrm{C}$ for $60 \mathrm{~min}$. The insulin released in the supernatant fractions was then measured by radioimmunoassay (Biotrak; GE Healthcare, Chalfont St Giles, UK).

Generation of recombinant adiponectin Bacterially expressed murine full-length adiponectin was generated as described previously $[7,11]$. The endotoxin content of the purified protein was determined using a Limulus Amebocyte Lysate Assay (Bio Whittaler, Walkersville, MD, USA). Mammalian adiponectin was purchased from Alexis Biochemicals (San Diego, CA, USA).

Glucose oxidation and fatty acid oxidation Glucose oxidation in the islets was evaluated by measuring the ${ }^{14} \mathrm{CO}_{2}$ generation from D- $\left[6-{ }^{14} \mathrm{C}\right]$ glucose [16]. Batches of ten freshly isolated islets were incubated at $37^{\circ} \mathrm{C}$ for $60 \mathrm{~min}$ in $\mathrm{KRB}$ containing $29.6 \mathrm{kBq}$ D- $\left[6-{ }^{14} \mathrm{C}\right]$ glucose and 5.6 or $22.2 \mathrm{mmol} / 1$ glucose with and without $10 \mu \mathrm{g} / \mathrm{ml}$ adiponectin. For fatty acid oxidation, batches of ten freshly isolated islets were incubated at $37^{\circ} \mathrm{C}$ for $60 \mathrm{~min}$ in $\mathrm{KRB}$ containing $25.9 \mathrm{kBq}$ [U- $\left.{ }^{14} \mathrm{C}\right]$ palmitic acid, $1 \mathrm{mmol} / 1$ carnitine, and 5.6 or 
$22.2 \mathrm{mmol} / \mathrm{l}$ glucose with and without $10 \mu \mathrm{g} / \mathrm{ml}$ adiponectin. The ${ }^{14} \mathrm{CO}_{2}$ produced was volatilised by adding $\mathrm{HCl}$, captured with Solvable (Packard Instrument Company, Meriden, CT, USA) and measured by liquid scintillation counting.

ATP and cAMP content The ATP and cAMP contents of the islets were determined as described previously [17]. Briefly, batches of ten islets were incubated at $37^{\circ} \mathrm{C}$ for $60 \mathrm{~min}$ in $\mathrm{KRB}$ containing $5.6 \mathrm{mmol} / \mathrm{l}$ glucose with and without $10 \mu \mathrm{g} / \mathrm{ml}$ adiponectin. Incubation was stopped by the addition of ice-cold $\mathrm{HClO}_{4}$ and the islets were homogenised by sonication. The lysates were neutralised by the addition of $\mathrm{NaOH}$. The ATP content and cAMP content of the supernatant fraction were measured using a bioluminescent assay kit (Sigma) and an enzyme-linked immunoassay kit (GE Healthcare), respectively.

Electrical recordings Electrophysiological experiments on the islets were performed using cells in situ in intact pancreatic islets. The islets were washed extensively in collagenase-free solution and then maintained in a shortterm tissue culture $(<24 \mathrm{~h})$ in RPMI 1640 containing $10 \%$ (vol./vol.) fetal calf serum supplemented with $100 \mu \mathrm{g} / \mathrm{ml}$ streptomycin and $100 \mathrm{IU} / \mathrm{ml}$ penicillin.

To establish the whole-cell mode, the amphotericin Bperforated patch-clamp technique was used. The membrane potential and the current of superficial cells in the intact pancreatic islets were recorded using an EPC-9 patch-clamp amplifier (HEKA Electronics, Lambrecht/Pfalz, Germany). The beta cells were identified by the lack of inward $\mathrm{Na}^{+}$ currents in the presence of a depolarising pulse from -70 to $0 \mathrm{mV}$ (5 $\mathrm{ms}$ in duration) [18]. The capacitance measurements were performed using software-based lock-in software (Pulse version 8.11; HEKA Electronics). The changes in cell capacitance were estimated by the Lindau-Neher technique $[19,20]$ by implementing the 'Sine $+\mathrm{DC}$ ' feature of the lock-in module. The amplitude of the sine wave was $20 \mathrm{mV}$ and the frequency was set at $1250 \mathrm{~Hz}$. Patch pipettes (tip resistance 5-7 M $\Omega$ when filled with the pipette solution) were pulled from borosilicate tubing. The capacitance measurements were performed at $32-34^{\circ} \mathrm{C}$. Capacitance was measured again $2 \mathrm{~min} 30 \mathrm{~s}$ after treatment with or without adiponectin. The standard extracellular medium consisted of $120 \mathrm{mmol} / \mathrm{l} \mathrm{NaCl}, 20 \mathrm{mmol} / \mathrm{l}$ tetraethylammonium-Cl, $3.6 \mathrm{mmol} / 1 \mathrm{KCl}, 2 \mathrm{mmol} / 1 \mathrm{NaHCO}_{3}, 0.5 \mathrm{mmol} / 1 \mathrm{NaH}_{2} \mathrm{PO}_{4}$, $0.5 \mathrm{mmol} / 1 \mathrm{MgSO}_{4}, 5 \mathrm{mmol} / \mathrm{l} \mathrm{HEPES}$ (at $\mathrm{pH} 7.4$ ), $2.6 \mathrm{mmol} / \mathrm{l}$ $\mathrm{CaCl}_{2}$ and $5 \mathrm{mmol} / \mathrm{l}$ D-glucose. The pipette solution for the perforated patch was composed of $76 \mathrm{mmol} / 1 \mathrm{Cs}_{2} \mathrm{SO}_{4}$, $10 \mathrm{mmol} / 1 \mathrm{NaCl}, 10 \mathrm{mmol} / \mathrm{K} \mathrm{KCl}, 1 \mathrm{mmol} / 1 \mathrm{MgCl}_{2}$ and $5 \mathrm{mmol} / \mathrm{l}$ HEPES (at $\mathrm{pH} 7.35$ ).

The cytosolic $\mathrm{Ca}^{2+}$ concentration $\left(\left[\mathrm{Ca}^{2+}\right]_{\mathrm{c}}\right)$ was measured using fura-2 by exciting its fluorescence in a dualwavelength ratiometric mode at 340 and $380 \mathrm{~nm}$. The emission wavelength was filtered at $500 \mathrm{~nm} .\left[\mathrm{Ca}^{2+}\right]_{\mathrm{c}}$ was expressed as the $340: 380 \mathrm{~nm}$ ratio.

Western blot analysis Mouse islets were homogenised in ice-cold buffer A $(25 \mathrm{mmol} / \mathrm{l}$ Tris- $\mathrm{HCl}$; pH 7.4, $10 \mathrm{mmol} / \mathrm{l}$ sodium orthovanadate, $10 \mathrm{mmol} / \mathrm{l}$ sodium pyrophosphate, $100 \mathrm{mmol} / \mathrm{l}$ sodium fluoride, $10 \mathrm{mmol} / 1$ EDTA, $10 \mathrm{mmol} / 1$ EGTA and $1 \mathrm{mmol} / \mathrm{l}$ phenylmethylsulfonyl fluoride). Samples were separated on polyacrylamide gels and transferred to a nitrocellulose membrane (Schleicher \& Schuell, Dassel, Germany). Rabbit anti-phospho-AMPK $\alpha$ (Thr-172) antibody and rabbit AMPK $\alpha$ antibody were purchased from Cell Signaling (Beverly, MA, USA).

Total internal reflection fluorescence microscopy We performed total internal reflection fluorescence (TIRF) microscopy using an inverted microscope (IX70; Olympus, Tokyo, Japan) with a high-aperture objective lens (Apo $100 \times$ OHR, Na 1.65; Olympus) as described previously $[21,22]$. Mouse pancreatic islets were isolated by collagenase digestion. Isolated islets were dissociated into single cells by incubation in $\mathrm{Ca}^{2+}$-free $\mathrm{KRB}$ containing $1 \mathrm{mmol} / 1$ EGTA and the beta cells were cultured on high-refractiveindex glass (Olympus) coated with fibronectin (Koken, Tokyo, Japan). To label the insulin-containing granules, pancreatic beta cells were infected with recombinant adenovirus Adex1CA insulin green fluorescent protein (GFP) as described previously [22]. The experiments were performed 2 days after infection. To observe GFP, we used a $488 \mathrm{~nm}$ laser line for excitation. The procedure used to monitor the motion of GFP-labelled insulin granules in pancreatic beta cells by TIRF microscopy has been described elsewhere [21]. Infected cells on a glass coverslip (Olympus) were mounted in an open chamber and incubated for $30 \mathrm{~min}$ at $37^{\circ} \mathrm{C}$ in $\mathrm{KRB}$ and $0.3 \%$ (wt/vol.) bovine serum albumin in the presence of $2.8 \mathrm{mmol} / 1$ glucose. The cells were then transferred to a thermostatically controlled stage $\left(37^{\circ} \mathrm{C}\right)$ and stimulated with $10 \mu \mathrm{g} / \mathrm{ml}$ adiponectin in the presence of $5.6 \mathrm{mmol} / \mathrm{l}$ glucose in the chamber. Diodomethane sulphur immersion oil (Cargille Laboratories, Cedar Grove, NJ, USA) was used to establish contact between the objective lens and the coverslip. The space constant for the exponential decay of the evanescent field was approximately $43 \mathrm{~nm}$.

Image acquisition and analysis Images were acquired every $300 \mathrm{~ms}$ with a cooled charge-coupled-device camera (DV887DCSBV; Andor Technology, South Windsor, CT, USA) operated with Metamorph 6.2 software (Universal Imaging, Downingtown, PA, USA). Most analyses, including tracking (single projection of difference images) and area calculations, were performed with the Metamorph software. To analyse the data, fusion events were selected 
a

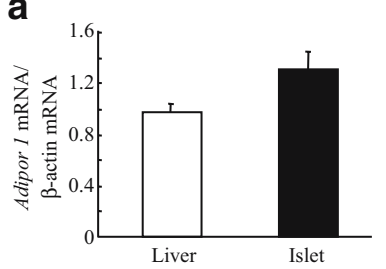

b
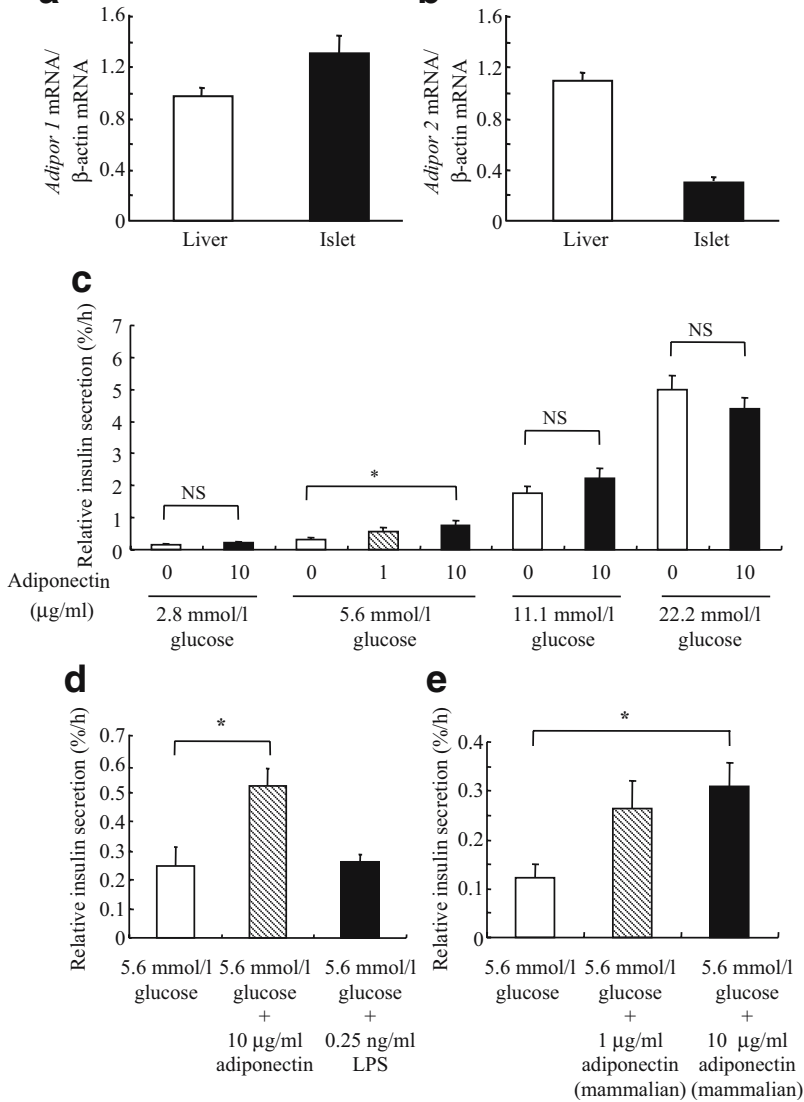

Fig. 1 Adiponectin stimulates insulin secretion from islets. TaqMan RT-PCR of Adipor1 $(n=3)$ (a) and Adipor2 $(n=3)$ (b) in mouse pancreatic islets. c Islets were incubated in KRB containing the indicated concentrations of glucose with or without adiponectin $(n=9-20)$. d Islets were incubated with glucose and with adiponectin or LPS $(n=3)$. e Islets were incubated with glucose with or without mammalian-derived adiponectin $(n=3)$. Values are means \pm SEM. $* p<0.05$

manually and the average fluorescence intensity of the individual granules in a $1 \times 1 \mu \mathrm{m}$ square placed over the granule centre was calculated. The number of fusion events was counted manually while looping approximately 15,000 time-lapsed frames. The sequences were exported as single TIRF files and further processed using Adobe Photoshop 6.0 software or converted into Quick Time movies.

Insulin secretion study in vivo Four days before the insulin secretion study, a catheter consisting of a silicone part (Phicon Tube; Fuji Systems, Tokyo, Japan) and a polyethylene part (PE-50; BD Biosciences, Franklin Lakes, NJ, USA) was inserted into the right jugular vein of animals under general anaesthesia with sodium pentobarbital, to administer infusions. The studies were performed on the mice under conscious, unstressed conditions after $24 \mathrm{~h}$ fast. D-Glucose $(0.2 \mathrm{~g} / \mathrm{kg})$ was injected intravenously through the catheter, either alone or with $0.6 \mathrm{mg} / \mathrm{kg}$ adiponectin. Blood samples were collected into a heparinised tube before and 10 and
20 min after the injection. After immediate centrifugation, the plasma was separated and stored at $-20{ }^{\circ} \mathrm{C}$ until analysed.

Insulin levels were determined by radioimmunoassay. The insulin to glucose ratio was calculated using the formulas: (10 $\mathrm{min}$ insulin level-fasting insulin level)/(10 $\mathrm{min}$ blood glucose level-fasting blood glucose) or (20 min insulin levelfasting insulin level)/(20 min blood glucose level-fasting blood glucose level). The adiponectin levels were determined with a mouse adiponectin ELISA kit (Otsuka, Tokyo, Japan). All data were obtained from six independent experiments.

Statistical analysis The statistical significance of differences between groups was determined using Student's $t$ test for unpaired comparisons, the Welch test, Dunnett's $t$ test or Steel's $z$ test. A $p$ value of $<0.05$ was regarded as significant.

\section{Results}

Adiponectin stimulates insulin secretion from mouse pancreatic islets at low glucose concentration We first confirmed the expression of Adipor1 and Adipor2 in mouse pancreatic islets (Fig. 1a,b), obtaining results that were essentially consistent with those previously reported [12]. We next examined the effect of adiponectin on glucose-induced insulin secretion from isolated islets during a $60 \mathrm{~min}$ static incubation (Fig. 1c). Adiponectin significantly stimulated insulin secretion to 2.3 -fold the baseline value at a $5.6 \mathrm{mmol} / 1$ glucose concentration ( $p=0.012$; Fig. 1c). However, adiponectin did not significantly increase insulin secretion in the presence of 11.1 or $22.2 \mathrm{mmol} / 1$ glucose. Since high concentrations of lipopolysaccharide (LPS) have been reported to stimulate insulin secretion from islets [23], we investigated the effect of LPS on insulin secretion from islets at $5.6 \mathrm{mmol} / \mathrm{l}$ glucose. When mouse pancreatic islets were treated with LPS at the same quantity as was present in recombinant adiponectin derived from Escherichia coli, no effect of LPS was found on insulin secretion (Fig. 1d). In addition, $10 \mu \mathrm{g} / \mathrm{ml}$ mammalian-derived adiponectin also stimulated insulin secretion from mouse pancreatic islets ( $p=0.039$; Fig. 1e). These results suggest that adiponectin acts directly on beta cells to increase insulin secretion.

Adiponectin stimulates insulin secretion without causing ATP generation, palmitic acid oxidation or cAMP generation in islets To examine the effect of adiponectin on ATP generation, we measured glucose-induced changes in D- $\left[6-{ }^{14} \mathrm{C}\right]$ glucose oxidation and the ATP content of islets (Table 1). $\mathrm{D}-\left[6-{ }^{14} \mathrm{C}\right]$ Glucose oxidation to ${ }^{14} \mathrm{CO}_{2}$ in the control islets increased 5.5-fold when the extracellular glucose concentration was raised from 5.6 to $22.2 \mathrm{mmol} / \mathrm{l}$. Adiponectin at a concentration of $10 \mu \mathrm{g} / \mathrm{ml}$ did not affect D- $\left[6-{ }^{14} \mathrm{C}\right]$ glucose oxidation in the presence of $5.6 \mathrm{mmol} / \mathrm{l}$ of glucose 
compared with control. In the presence of $22.2 \mathrm{mmol} / \mathrm{l}$ glucose, adiponectin also failed to significantly change $\mathrm{D}-\left[6-{ }^{14} \mathrm{C}\right]$ glucose oxidation compared with control islets incubated at the same glucose concentration. Next, we measured the ATP content of islets to directly monitor the efficiency of mitochondrial ATP synthesis. The results showed that adiponectin at a concentration of $10 \mu \mathrm{g} / \mathrm{ml} \mathrm{did}$ not affect ATP content in the presence of $5.6 \mathrm{mmol} / \mathrm{l}$ glucose (Table 1). The above findings indicate that adiponectin has no stimulatory effect on ATP generation from mitochondrial glucose metabolism. Increase in cAMP content potentiates glucose-stimulated insulin secretion through activation of cAMP-dependent protein kinase [24]. Adiponectin also failed to significantly change the cAMP content as compared with control islets (Table 1). Although adiponectin has been reported to reduce elevated fatty acid levels in muscle by oxidising fatty acids [7-9], no significant change in the oxidation of palmitic acid was observed in pancreas islets treated with adiponectin as compared with control at 5.6 or $22.2 \mathrm{mmol} / \mathrm{l}$ of glucose (Table 1).

Adiponectin stimulates insulin secretion without causing membrane depolarisation, closure of $K_{A T P}^{+}$- channels or $\mathrm{Ca}^{2+}$ entry into the cytosol We measured the membrane potentials of pancreatic beta cells to determine whether adiponectin caused membrane depolarisation. In the presence of $5.6 \mathrm{mmol} / \mathrm{l}$ glucose, adiponectin at a concentration of $10 \mu \mathrm{g} / \mathrm{ml}$ had no effect on the membrane potentials (Fig. 2a), but membrane of pancreatic beta cells depolarised when the extracellular glucose level was raised from 5.6 to $22.2 \mathrm{mmol} / 1$ (Fig. 2a). Figure 2b shows the current-voltage relationship for $\mathrm{Ca}^{2+}$ currents. When the membrane potential was held at $-70 \mathrm{mV}, \mathrm{Ca}^{2+}$ currents elicited by $200 \mathrm{~ms}$ depolarising voltage-clamp pulses from -40 to $40 \mathrm{mV}$ were applied in the presence of $5.6 \mathrm{mmol} / \mathrm{l}$ glucose. Adiponectin at a concentration of $10 \mu \mathrm{g} / \mathrm{ml}$ did not change the currentvoltage curve via $\mathrm{Ca}^{2+}$ influx into the cytosol (Fig. 2b). To investigate the effect of adiponectin on the increase in the $\left[\mathrm{Ca}^{2+}\right]_{\mathrm{c}}$, we monitored the fluorescence of fura-2/acetoxymethyl ester excited at 340 and $380 \mathrm{~nm}$ in perifused islets
(Fig. 2c). The 340:380 $\mathrm{nm}$ fluorescence ratio increased in islets when the glucose concentration was raised from 5.6 to $22.2 \mathrm{mmol} / \mathrm{l}$, but adiponectin had no effect on the $\left[\mathrm{Ca}^{2+}\right]_{\mathrm{c}}$ (Fig. 2c). To clarify whether adiponectin stimulates insulin secretion without causing $\mathrm{Ca}^{2+}$ influx, we next investigated the effects of adiponectin on mouse pancreatic islets in the presence of the L-type $\mathrm{Ca}^{2+}$-channel blocker, nitrendipine. Nitrendipine at a concentration of $5 \mu \mathrm{mol} / 1$ is known to inhibit $\mathrm{Ca}^{2+}$ influx [25]. Nevertheless, insulin secretion was markedly diminished at $22.2 \mathrm{mmol} / \mathrm{l}$ glucose in the presence of nitrendipine, whereas adiponectin significantly stimulated insulin secretion at $5.6 \mathrm{mmol} / 1$ glucose ( $p=0.043$; Fig. $2 \mathrm{~d}$ ). Interestingly, adiponectin also significantly stimulated insulin secretion at $22.2 \mathrm{mmol} / \mathrm{l}$ glucose concentration in the presence of nitrendipine ( $p=0.047)$ (Fig. 2d). These findings suggest that adiponectin is able to stimulate insulin secretion when the influx of $\mathrm{Ca}^{2+}$ through voltage-dependent $\mathrm{Ca}^{2+}$ channels is blocked.

AMPK is not involved in adiponectin-stimulated insulin secretion Adiponectin has been previously reported to improve insulin sensitivity in muscle and liver by enhancing fatty acid oxidation via the activation of AMPK [7, 8], which has been found to increase glucose transport by stimulating the translocation of GLUT4 [26, 27]. To elucidate whether AMPK might be involved in adiponectin-stimulated insulin secretion, we examined the effect of adiponectin on phosphorylation of AMPK in mouse pancreatic islets. However, adiponectin did not affect the phosphorylation of AMPK at $5.6 \mathrm{mmol} / \mathrm{l}$ glucose (Fig. 3a). The AMPK activator 5-amino-imidazole-4-carboxamide riboside (AICAR), on the other hand, significantly increased the phosphorylation of AMPK at $5.6 \mathrm{mmol} / 1$ glucose $(p=0.00083$; Fig. 3b). However, AICAR significantly decreased insulin secretion from mouse pancreatic islets $(p=0.024$; Fig. $3 c)$ [28]. These results suggest that AMPK is not involved in adiponectinstimulated insulin secretion at low glucose concentrations.

Adiponectin stimulates insulin release via induction of increased fusion events at a low glucose concentration We

Table 1 Adiponectin stimulates insulin secretion without causing ATP generation, palmitic acid oxidation or cAMP generation in islets

\begin{tabular}{|c|c|c|c|c|c|c|}
\hline \multirow[b]{2}{*}{ Glucose (mmol/l) } & \multicolumn{2}{|c|}{$\begin{array}{l}\mathrm{D}-\left[6-{ }^{14} \mathrm{C}\right] \text { Glucose oxidation } \\
\left(\mathrm{pmol} \mathrm{h}^{-1} \text { islet }^{-1}\right)\end{array}$} & \multirow{2}{*}{$\begin{array}{l}\begin{array}{l}\text { ATP content } \\
\text { (pmol/islet) }\end{array} \\
5.6\end{array}$} & \multicolumn{2}{|c|}{$\begin{array}{l}{\left[\mathrm{U}^{14}{ }^{14} \mathrm{C}\right] \text { Palmitic acid oxidation }} \\
\left(\mathrm{fmol} \mathrm{h}^{-1} \text { islet }^{-1}\right)\end{array}$} & \multirow{2}{*}{$\begin{array}{l}\begin{array}{l}\text { cAMP conten } \\
\text { (fmol/islet) }\end{array} \\
5.6\end{array}$} \\
\hline & 5.6 & 22.2 & & 5.6 & 22.2 & \\
\hline Control & $1.92 \pm 0.27$ & $10.6 \pm 1.1^{\mathrm{b}}$ & $1.16 \pm 0.09$ & $2.98 \pm 0.20$ & $2.41 \pm 0.07^{\mathrm{a}}$ & $49 \pm 7$ \\
\hline$n$ & 4 & 4 & 5 & 4 & 4 & 5 \\
\hline Adiponectin & $2.37 \pm 0.22$ & $11.7 \pm 1.8^{\mathrm{b}}$ & $1.29 \pm 0.08$ & $3.23 \pm 0.23$ & $2.59 \pm 0.10^{\mathrm{a}}$ & $62 \pm 10$ \\
\hline$n$ & 4 & 4 & 5 & 4 & 4 & 5 \\
\hline
\end{tabular}

Values are means \pm SEM.

${ }^{\mathrm{a}} p<0.05,{ }^{\mathrm{b}} p<0.01$ compared with the $5.6 \mathrm{mmol} / 1$ glucose group 
then examined the capacitance of mouse pancreatic beta cells. The technique used is characterised by high time resolution and thus can detect dynamic changes in the cell surface area that reflect exocytosis. Figure 4a shows the capacitance of mouse pancreatic beta cells. Interestingly, adiponectin at a concentration of $10 \mu \mathrm{g} / \mathrm{ml}$ significantly increased the capacitance of mouse pancreatic beta cells to 2.3 -fold above baseline $(p=0.0091$; Fig. 4a), indicating that adiponectin may stimulate insulin granule exocytosis in the absence of any changes in membrane depolarisation, $\mathrm{Ca}^{2+}$ currents or $\left[\mathrm{Ca}^{2+}\right]_{\mathrm{c}}$.

To elucidate the mechanism by which adiponectin increased the exocytosis of insulin-containing granules, we used TIRF microscopy to monitor the real-time docking and fusion process of single insulin granules labelled with a GFP-tagged insulin near the plasma membrane in mouse pancreatic beta cells. Interestingly, adiponectin significantly increased the number of fusion events by newcomers $(40.5 \pm$ 4.1 per $200 \mu^{2}$ in $0-30 \mathrm{~min}$ control beta cells vs $72.3 \pm 6.5$ per $200 \mu \mathrm{m}^{2}$ in $0-30 \mathrm{~min}$ adiponectin-treated beta cells, $p<$ $0.0005, n=45$ for control and $n=52$ for adiponectin-treated cells; Fig. 4b,c and Electronic supplementary material [ESM], video clips), suggesting that adiponectin may accelerate transport of insulin granules from a cytoplasmic pool to the plasma membrane.

Adiponectin stimulates insulin secretion in vivo To elucidate the physiological roles of adiponectin in insulin secretion in vivo, we studied the effect of adiponectin on insulin secretion in $\mathrm{C} 57 \mathrm{BL} / 6$ mice after intravenous transcatheter injection of adiponectin and a low concentration of glucose. We tried to adjust the blood glucose level to approximately $5.6 \mathrm{mmol} / \mathrm{l}$. Figure 5 a shows the plasma adiponectin level at 10 and $20 \mathrm{~min}$ after the intravenous injection of glucose and saline or adiponectin. The plasma adiponectin levels increased significantly to 1.8 fold of baseline following the injection of adiponectin, while the increased blood glucose levels at 10 and $20 \mathrm{~min}$ after the injection were not significantly different between the two groups (Fig. 5b). The blood glucose level and insulin level at the starting point were $3.7 \pm 0.4 \mathrm{mmol} / \mathrm{l}$ and $36.2 \pm 5.0 \mathrm{pmol} / 1$, respectively. No significant differences in the increased plasma insulin levels at $10 \mathrm{~min}$ after administration were observed between the adiponectin and the saline groups (Fig. 5c). However, the increase in plasma insulin levels at $20 \mathrm{~min}$ after the intravenous injection of glucose was approximately 1.6 -fold greater in the adiponectin group $(n=19)$ than in the saline group $(n=21 ; p=0.048$; Fig. 5 c $)$. We evaluated the changes in ratio of the increment of plasma insulin level to that of blood glucose level. At $20 \mathrm{~min}$ after glucose loading the ratio in the adiponectin group was approximately sevenfold higher than that in the saline group $(p=0.0088)$ (Fig. 5d). These results suggest that adiponectin stimulates insulin secretion in vivo.
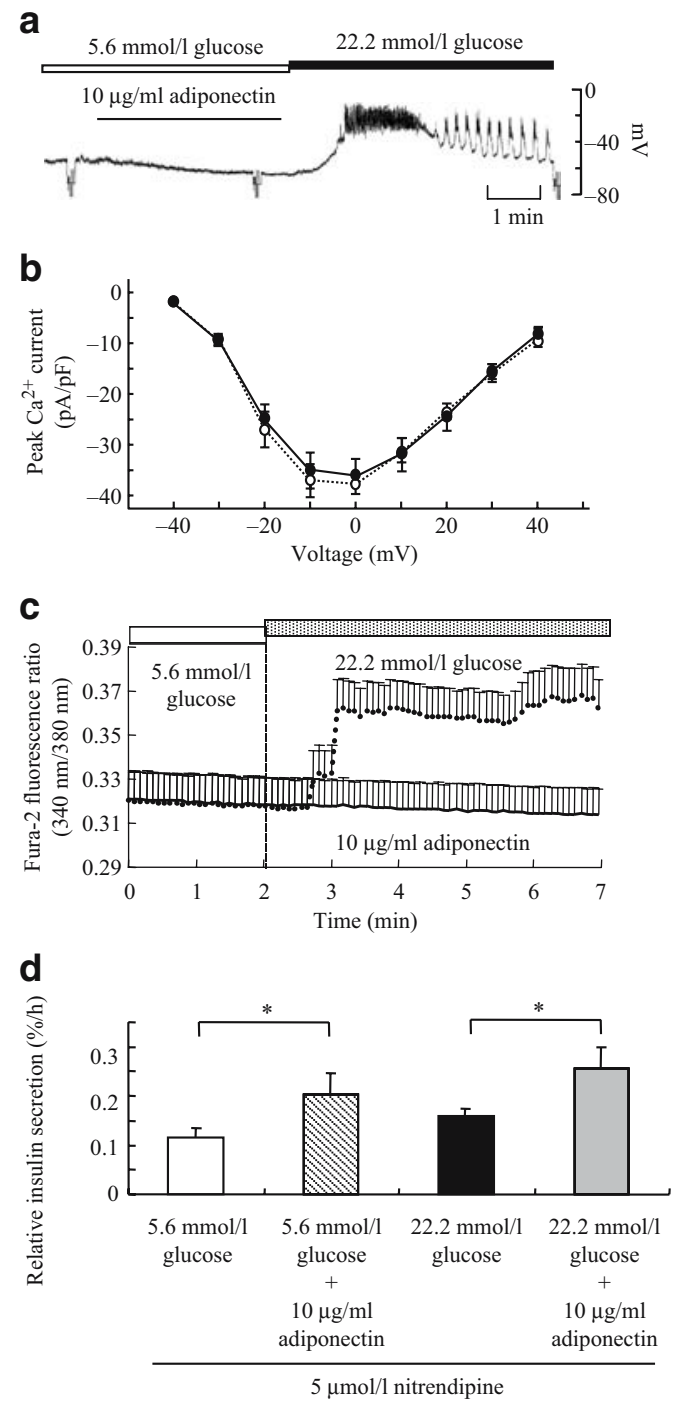

Fig. 2 Adiponectin stimulates insulin secretion without causing membrane depolarisation, closure of $\mathrm{K}_{\mathrm{ATP}}^{+}-$channels or $\mathrm{Ca}^{2+}$ entry into the cytosol. a Membrane potentials in response to the addition of adiponectin and increasing concentrations of glucose (5.6-22.2 mmol/1) were recorded under the conventional whole-cell mode. Results are representative of three independent experiments. b The current-voltage relationships of beta cells treated with (black circles, $n=3$ ) or without (white circles, $n=3$ ) adiponectin $(10 \mu \mathrm{g} / \mathrm{ml})$. c Cytosolic calcium concentrations in response to the addition of adiponectin and increasing concentrations of glucose were measured using fura-2. Mean values are shown $(n=5)$. d Islets were incubated in KRB containing the indicated concentrations of glucose and $5 \mu \mathrm{mol} / 1$ nitrendipine with or without $10 \mu \mathrm{g} / \mathrm{ml}$ adiponectin $(n=18-23)$. Values are means \pm SEM. $* p<0.05$

\section{Discussion}

In this study we have shown that adiponectin stimulates insulin secretion in vitro and in vivo. In addition, our results also indicate that adiponectin stimulates insulin secretion without causing ATP generation, closure of $\mathrm{K}_{\mathrm{ATP}}^{+}-$ channels, $\mathrm{Ca}^{2+}$ entry into the cytosol or activation of AMPK. 
a

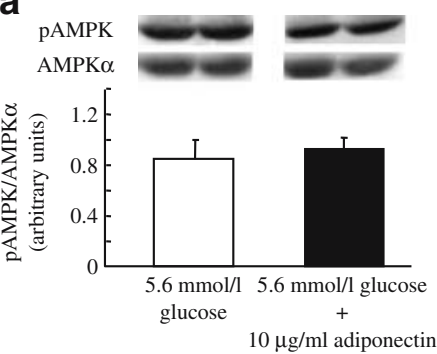

b

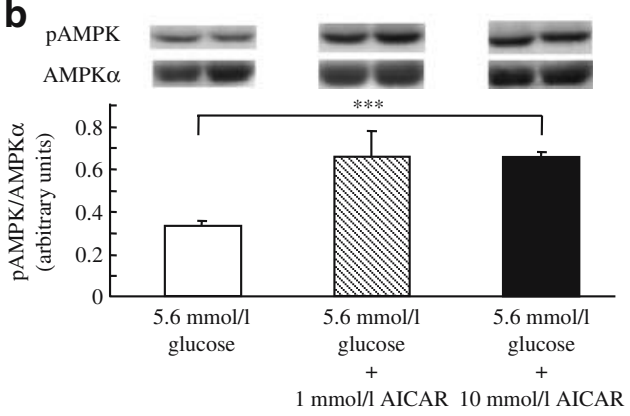

C

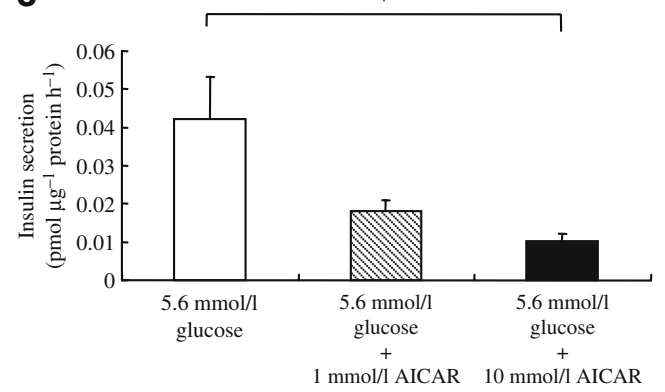

Fig. 3 Adiponectin stimulates insulin secretion without causing activation of AMPK. a, b Western blots of phosphorylated AMPK and AMPK $\alpha$ in mouse pancreatic islets ( $n=3$, each group). Lysates from 30 islets from each group were subjected to western blot analysis. c Isolated islets were incubated with AICAR at $5.6 \mathrm{mmol} / 1$ glucose. Values are means \pm SEM. ${ }^{*} p<0.05,{ }^{* * *} p<0.001$

Adiponectin has previously been reported to increase fatty acid oxidation via activation of AMPK [7, 8], which has been found to increase glucose transport by stimulating the translocation of GLUT4 to the sarcolemma in heart [26] and skeletal muscle [27]. However, adiponectin did not affect the phosphorylation of AMPK in pancreatic islets at $5.6 \mathrm{mmol} /$ 1 glucose. Since AMPK in pancreatic beta cells is activated by low glucose concentrations [28], adiponectin may be unable to further activate AMPK at this low glucose concentration. By contrast, although the AMPK activator AICAR activated AMPK at this low glucose concentration, AICAR also decreased insulin secretion under these conditions. These results indicate that AMPK is not involved in adiponectinstimulated insulin secretion at a low glucose concentration.

This study has shown that adiponectin stimulated insulin secretion without causing $\mathrm{Ca}^{2+}$ entry into the cytosol. The following cascade is generally accepted to be involved in glucose-induced insulin secretion. When glucose is metabolised in the cytosol and mitochondria, ATP is generated and promotes the closure of ATP-sensitive potassium channels, thereby depolarising the plasma membrane potential. Depolarisation of the plasma membrane leads to activation of voltage-dependent $\mathrm{Ca}^{2+}$ channels, $\mathrm{Ca}^{2+}$ entry into the cytosol and a rise in $\left[\mathrm{Ca}^{2+}\right]_{\mathrm{c}}$, which is thought to finally trigger the exocytosis of insulin-containing granules [29-31]. However, a $\mathrm{Ca}^{2+}$-independent pathway has also been proposed. Thus, Komatsu et al. have suggested that both $\mathrm{Ca}^{2+}$-dependent and $\mathrm{Ca}^{2+}$-independent augmentation occurs via a pathway dependent on glucose metabolism $[32,33]$. In this context, we confirmed that adiponectin is able to stimulate insulin secretion when the influx of $\mathrm{Ca}^{2+}$ through voltage-dependent $\mathrm{Ca}^{2+}$ channels is blocked by nitrendipine; in other words, adiponectin stimulates insulin
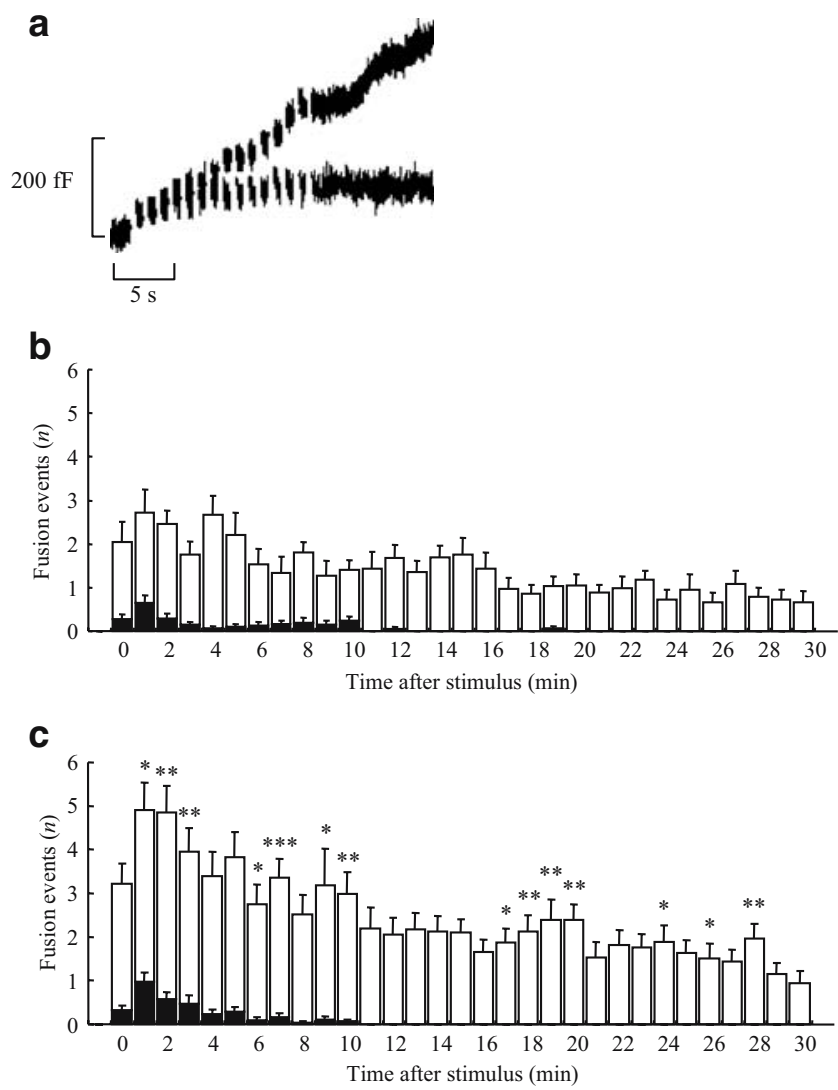

Fig. 4 Adiponectin stimulates insulin release via induction of increased fusion events. a The membrane capacitance of mouse beta cells exposed to $5.6 \mathrm{mmol} / 1$ glucose alone (lower curve) and $5.6 \mathrm{mmol} / 1$ glucose + $10 \mu \mathrm{g} / \mathrm{ml}$ adiponectin (upper curve) cumulatively increased upon repetitive application of depolarising pulses and then plateaued (glucose alone). The traces shown are representative of three experiments. b, c TIRF images were acquired every $300 \mathrm{~ms}$ after the addition of adiponectin. The fusion events per $200 \mu^{2}$ were counted manually. Histograms of the number of fusion events in $5.6 \mathrm{mmol} / \mathrm{l}$ glucose in the absence (b) $(n=45)$ and presence $(\mathbf{c})(n=52)$ of adiponectin $(10 \mu \mathrm{g} / \mathrm{ml})$. Black bars, previously docked granules; white bars, newly docked granules. Values are mean \pm SEM. ${ }^{*} p<0.05,{ }^{* *} p<0.01, * * * p<0.005$ 

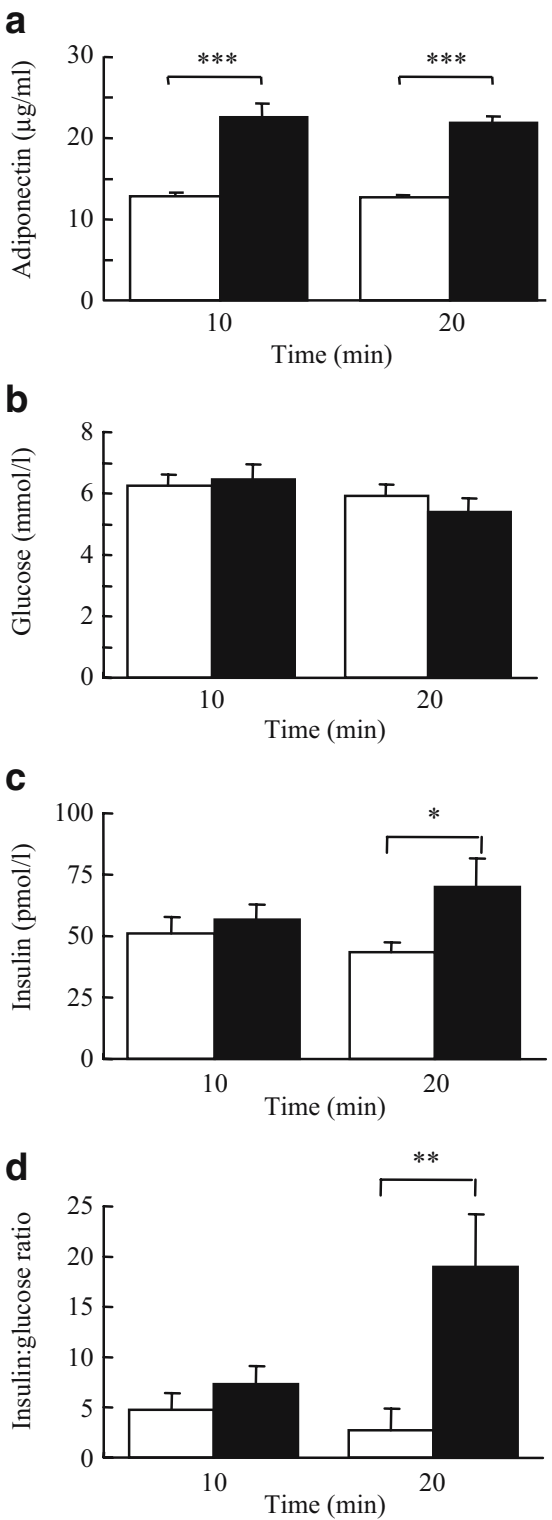

Fig. 5 Adiponectin stimulates insulin secretion in vivo. a Plasma adiponectin level after intravenous injection of glucose and saline (white bars, $n=8-21$ ) or adiponectin (black bars, $n=8-19$ ). b Blood glucose and (c) plasma insulin levels after the intravenous injections. d Ratio of the increment in plasma insulin level to that of blood glucose level after the intravenous injections. Values are means \pm SEM. ${ }^{*} p<0.05,{ }^{* *} p<0.01, * * * p<0.005$

secretion without requiring influx of $\mathrm{Ca}^{2+}$ through voltagedependent $\mathrm{Ca}^{2+}$ channels. It may do this through these augmentation pathways triggered by glucose metabolism [33], namely by replacing part of the $\mathrm{Ca}^{2+}$-dependent/ $\mathrm{Ca}^{2+}$ independent augmentation on newly docked granules. In this regard, it should be noted that adiponectin was able to stimulate insulin secretion at $22.2 \mathrm{mmol} / \mathrm{l}$ glucose when the influx of $\mathrm{Ca}^{2+}$ was blocked by nitrendipine (Fig. 2d). The observation that this stimulation of insulin secretion by adiponectin is relatively small as compared with that of glucose itself under physiological conditions (Fig. 1c) may reflect the relatively small role of the $\mathrm{Ca}^{2+}$-independent augmentation pathway, as suggested by Sato et al. [34].

As another possible mechanism, adiponectin may affect remodelling of the cytoskeleton. The cytoskeleton plays a critical role in glucose-stimulated intracellular trafficking and the exocytosis of insulin-containing granules at the plasma membrane of beta cells. In fact, a previous report showed direct evidence of a dynamic interaction between target membrane soluble $\mathrm{N}$-ethylmaleimide-sensitive factor attachment protein receptor protein and $\mathrm{F}$-actin during glucose-stimulated insulin secretion in MIN6 cells [35]. It was recently reported that calpain plays a role in facilitating the actin reorganisation required for glucose-stimulated insulin secretion [36]. Another study has suggested that kinesin I plays an important role in the microfilamentdependent movements of insulin containing granules [37]. Adiponectin may cause direct activation of calpain or kinesin I, to influence remodelling of the cytoskeleton.

Conflicting results on the effects of adiponectin on insulin secretory function in vitro have been reported so far. A previous study showed that while adiponectin decreased glucose/forskolin-induced insulin secretion, it reversed NEFA-induced inhibition of insulin secretion [13]. Another group reported that adiponectin had no effect on either basal or stimulated insulin secretion from human islets [38]. Winzell et al. [39] reported that adiponectin decreases insulin secretion from the pancreatic islets of insulin-resistant mice at a $2.8 \mathrm{mmol} / 1$ glucose, but stimulates insulin secretion at $16.7 \mathrm{mmol} / \mathrm{l}$ glucose. However, there have been no reports on the effects of adiponectin on insulin secretion in vivo. This study is the first study to demonstrate that adiponectin stimulates insulin secretion not only in vitro, but also in vivo.

In conclusion, we have described a novel effect of adiponectin, namely stimulation of insulin secretion, in addition to its known insulin-sensitising and anti-atherogenic effects. Consequently, adiponectin receptor agonists may be useful in the activation of adiponectin signalling as a new therapeutic strategy for treating diabetes and atherogenic diseases.

Acknowledgements We thank A. Ohyama, C. Kokaki-Kaizuka, N. Kowatari-Otsuka, K. Takasawa and H. Chiyonobu for their excellent technical assistance and mouse husbandry.

Duality of interest The authors declare that there is no duality of interest associated with this manuscript.

\section{References}

1. Scherer PE, Williams S, Fogliano M, Baldini G, Lodish HF (1995) A novel serum protein similar to $\mathrm{C} 1 \mathrm{q}$, produced exclusively in adipocytes. J Biol Chem 270:26746-26749

2. Hu E, Liang P, Spiegelman BM (1996) AdipoQ is a novel adipose-specific gene dysregulated in obesity. J Biol Chem 271: 10697-10703 
3. Maeda K, Okubo K, Shimomura I, Funahashi T, Matsuzawa Y, Matsubara K (1996) cDNA cloning and expression of a novel adipose specific collagen-like factor, apM1 (AdiPose Most abundant Gene transcript 1). Biochem Biophys Res Commun 221:286-296

4. Nakano Y, Tobe T, Choi-Miura NH, Mazda T, Tomita M (1996) Isolation and characterization of GBP28, a novel gelatin-binding protein purified from human plasma. J Biochem (Tokyo) 120: 803-812

5. Arita Y, Kihara S, Ouchi N et al (1999) Paradoxical decrease of an adipose-specific protein, adiponectin, in obesity. Biochem Biophys Res Commun 257:79-83

6. Yamauchi T, Kamon J, Waki H et al (2001) The fat-derived hormone adiponectin reverses insulin resistance associated with both lipoatrophy and obesity. Nat Med 7:941-946

7. Yamauchi T, Kamon J, Minokoshi Y et al (2002) Adiponectin stimulates glucose utilization and fatty-acid oxidation by activating AMP-activated protein kinase. Nat Med 8:1288-1295

8. Tomas E, Tsao TS, Saha AK et al (2002) Enhanced muscle fat oxidation and glucose transport by ACRP30 globular domain: acetylCoA carboxylase inhibition and AMP-activated protein kinase activation. Proc Natl Acad Sci U S A 99:16309-16313

9. Fruebis J, Tsao TS, Javorschi S et al (2001) Proteolytic cleavage product of $30-\mathrm{kDa}$ adipocyte complement-related protein increases fatty acid oxidation in muscle and causes weight loss in mice. Proc Natl Acad Sci U S A 98:2005-2010

10. Kubota N, Terauchi Y, Yamauchi T et al (2002) Disruption of adiponectin causes insulin resistance and neointimal formation. $\mathrm{J}$ Biol Chem 277:25863-25866

11. Yamauchi T, Kamon J, Ito Y et al (2003) Cloning of adiponectin receptors that mediate antidiabetic metabolic effects. Nature 423:762-769

12. Kharroubi I, Rasschaert J, Eizirik DL, Cnop M (2003) Expression of adiponectin receptors in pancreatic beta cells. Biochem Biophys Res Commun 312:1118-1122

13. Rakatzi I, Mueller H, Ritzeler O, Tennagels N, Eckel J (2004) Adiponectin counteracts cytokine- and fatty acid-induced apoptosis in the pancreatic beta-cell line INS-1. Diabetologia 47:249-258

14. Lacy PE, Malaisse WJ (1973) Microtubules and beta cell secretion. Recent Prog Horm Res 29:199-228

15. Eto K, Tsubamoto Y, Terauchi Y et al (1999) Role of NADH shuttle system in glucose-induced activation of mitochondrial metabolism and insulin secretion. Science 283:981-985

16. Schuit F, De Vos A, Farfari S et al (1997) Metabolic fate of glucose in purified islet cells. Glucose-regulated anaplerosis in beta cells. J Biol Chem 272:18572-18579

17. Malaisse WJ, Sener A (1987) Glucose-induced changes in cytosolic ATP content in pancreatic islets. Biochim Biophys Acta 927:190 195

18. Gopel S, Zhang Q, Eliasson L et al (2004) Capacitance measurements of exocytosis in mouse pancreatic alpha-, beta-, and deltacells within intact islets of Langerhans. J Physiol 556:711-726

19. Gillis KD (1995) Single-channel recording. Plenum, New York, pp 155-197

20. Kanno T, Ma X, Barg S et al (2004) Large dense-core vesicle exocytosis in pancreatic beta-cells monitored by capacitance measurements. Methods 33:302-311

21. Ohara-Imaizumi M, Nakamichi Y, Tanaka T, Ishida H, Nagamatsu S (2002) Imaging exocytosis of single insulin secretory granules with evanescent wave microscopy: distinct behavior of granule motion in biphasic insulin release. J Biol Chem 277: 3805-3808

22. Ohara-Imaizumi M, Nishiwaki C, Kikuta T, Nagai S, Nakamichi Y, Nagamatsu S (2004) TIRF imaging of docking and fusion of single insulin granule motion in primary rat pancreatic beta-cells: different behaviour of granule motion between normal and GotoKakizaki diabetic rat beta-cells. Biochem J 381:13-18

23. Vives-Pi M, Somoza N, Fernandez-Alvanrez J et al (2003) Evidence of expression of endotoxin receptors CD14, toll-like receptors TLR4 and TLR2 and associated molecule MD-2 and of sensitivity to endotoxin (LPS) in islet beta cells. Clin Exp Immunol 133:208-218

24. Eddlestone GT, Oldham SB, Lipson LG, Premdas FH, Beigelman PM (1985) Electrical activity, cAMP concentration, and insulin release in mouse islets of Langerhans. Am J Physiol 248:C145C153

25. Ikeda $Y$, Iguchi $H$, Nakata $M$ et al (2005) Identification of $N$ arachidonylglycine, U18666A, and 4-andorostene-3, 17-dione as novel insulin secretagogues. Biochem Biophys Res Commun 333:778-786

26. Russell RR 3rd, Bergeron R, Shulman GI, Young LH (1999) Translocation of myocardial GLUT4 and increased glucose uptake through activation of AMPK by AICAR. Am J Physiol 277: H643-H649

27. Kurth-Kraczek EJ, Hirshman MF, Goodyear LJ, Winder WW (1999) 5' AMP-activated protein kinase activation causes GLUT4 translocation in skeletal muscle. Diabetes 48:1667-1671

28. da Silva Xavier G, Leclerc I, Varadi A, Tsuboi T, Moule SK, Rutter GA (2003) Role for AMP-activated protein kinase in glucose-stimulated insulin secretion and preproinsulin gene expression. Biochem J 371:761-774

29. Ashcroft FM, Proks P, Smith PA, Ammala C, Bokvist K, Rorsman P (1994) Stimulus-secretion coupling in pancreatic beta cells. J Cell Biochem 55:54-65

30. Dukes ID, Philipson LH (1996) $\mathrm{K}^{+}$channels: generating excitement in pancreatic beta-cells. Diabetes 45:845-853

31. Wollheim CB, Lang J, Regazzi R (1996) The exocytotic process of insulin secretion and its regulation by $\mathrm{Ca}^{2+}$ and G-proteins. Diabetes Rev 4:276-297

32. Komatsu M, Schermerhorn T, Aizawa T, Sharp GW (1995) Glucose stimulation of insulin release in the absence of extracellular $\mathrm{Ca}^{2+}$ and in the absence of any increase in intracellular $\mathrm{Ca}^{2+}$ in rat pancreatic islets. Proc Natl Acad Sci U S A. 92:10728-10732

33. Komatsu M, Noda M, Sharp GW (1998) Nutrient augmentation of $\mathrm{Ca}^{2+}$-dependent and $\mathrm{Ca}^{2+}$-independent pathways in stimuluscoupling to insulin secretion can be distinguished by their guanosine triphosphate requirements: studies on rat pancreatic islets. Endocrinology 139:1172-1183

34. Sato Y, Nenquin M, Henquin JC (1998) Relative contribution of $\mathrm{Ca}^{2+}$-dependent and $\mathrm{Ca}^{2+}$-independent mechanisms to the regulation of insulin secretion by glucose. FEBS Lett 421:115-119

35. Thurmond DC, Gonelle-Gispert C, Furukawa M, Halban PA, Pessin JE (2003) Glucose-stimulated insulin secretion is coupled to the interaction of actin with the t-SNARE (target membrane soluble N-ethymaleimide-sensitive factor attachment protein receptor protein) complex. Mol Endocinol 17:732-742

36. Turner MD, Fulcher FK, Jones CV et al (2007) Calpain facilitates actin reorganization during glucose-stimulated insulin secretion. Biochem Biophys Res Commun 352:650-655

37. Varadi A, Tsuboi T, Johnson-Cadwell LI, Allan VJ, Rutter GA (2003) Kinesin I and cytoplasmic dynein orchestrate glucosestimulated insulin-containing vesicle movements in clonal MIN6 beta-cells. Biochem Biophys Res Commun 311:272-282

38. Staiger K, Stefan N, Staiger H et al (2005) Adiponectin is functionally active in human islets but does not affect insulin secretory function or beta-cell lipoapoptosis. J Clin Endocrinol Metab 90:6707-6713

39. Winzell MS, Nogueiras R, Dieguez C, Ahren B (2004) Dual action of adiponectin on insulin secretion in insulin-resistant mice. Biochem Biophys Res Commun 321:154-160 